\title{
INCREASING LEVELS OF LIVE KIDNEY TRANSPLANTATION IN NEW ZEALAND
}

\author{
Paula Martin
}

\begin{abstract}
A kidney transplant from a living donor is the preferred treatment for people with end-stage renal failure as it offers better outcomes for patients and is more cost effective than dialysis. The shortage of deceased organ donors means that a transplant from a live donor is the only transplant option for many people. However, there is a growing gap between the number of people needing kidney transplants and the number carried out each year. Maori and Pacific peoples, in particular, have lower rates of renal transplantation than other groups. The international literature suggests there may be options to consider for further enhancing policy and practice relating to live renal transplantation (LRT) in New Zealand; but there is little New Zealand-evidence about factors affecting rates of LRT. This article outlines the current problem of the gap between supply and demand for kidney transplants in New Zealand, framing this as a public policy problem, and suggesting LRT as an important strategy for addressing this issue. New Zealand-based research is required regarding the barriers to LRT and options for increasing current levels in New Zealand.
\end{abstract}

\section{INTRODUCTION}

The first successful live kidney transplant was carried out over 50 years ago (Murray, 1992). Live renal transplantation (LRT) is now widely regarded, by both clinicians and patients as the preferred treatment for people with endstage renal failure (ESRF); offering the best health outcomes and the greatest cost-effectiveness of any form of renal replacement therapy (RRT) (see, for example, Abecassis, et al., 2008; Davis \& Delmonico, 2005; Horvat, Shariff, \& Garg, 2009; Huang, Thakur, \& Meltzer, 2008; Sanner, Lagging, \& Tibell, 2011).

The demand for RRT, either dialysis or a transplant from a deceased or living donor, in New Zealand is predicted to continue to rise by about five per cent 
per annum, a rate higher than can be attributed to population growth alone. The increase in the level of Type II diabetes and improved survival rates of renal patients (due largely to better management of cardiovascular disease, a key co-morbidity of renal disease) account for much of this growth in demand (Ministry of Health, 2006).

This growing demand, however, is not matched by increases in rates of transplantation, with implications both for patients and their families and the government's health budget, which is under increasing pressure. While organ transplants from live and deceased donors are sometimes discussed interchangeably, a specific focus on the issues relating to live transplantation is necessary, particularly in the case of kidney disease, given the growing level of demand.

My interest in the topic of how rates of LRT might be increased derives from several sources in my personal and professional life. I was a live kidney donor in 2006 and spent two years on the Board of Kidney Health New Zealand. I regularly speak to individuals who are thinking about being a kidney donor or, more often, have already decided and just want to speak to someone else about 'what it's really like'. Being of Maori descent, I note with particular interest the public discussion about 'the Maori view' of organ donation and compare this with my own experiences and those of family and friends.

I have also been a policy analyst/policy manager for many years in the New Zealand public service, most recently in the Ministry of Health, focusing on issues of value for money, prioritisation and fiscal sustainability. Viewed through these lenses, increasing our rates of LRT would benefit both patients and government and, yet, it is not on the wider policy agenda.

My conversations with other live donors about their journey to becoming a donor, as well as others who are thinking about it, have prompted many thoughts about what the barriers to donation are and how they could be overcome. Are there other things New Zealand could be doing to facilitate live donation by people who are potentially motivated and willing (given the right information) that do not involve costly or socially unacceptable interventions? From the perspective of a health policy manager, I am interested in why this issue has not been a policy priority given the impact on health outcomes and fiscal costs to the government.

This article begins with an overview of the LRT situation in New Zealand and then outlines the problem, framing it as a public policy issue. I then outline 
some of what the international literature suggests about barriers to LRT and possible options for addressing them and suggest that there is a need for New Zealand-based research to inform policy and practice about the alternatives that might be considered here.

\section{BACKGROUND}

\section{LRT is the preferred treatment for ESRF}

End-stage renal failure is fatal, usually within weeks, without renal replacement therapy-either dialysis or a transplant from a live or deceased donor (Stein \& Wild, 2002). Like most countries, New Zealand has rising numbers of people with end-stage renal failure and increasing demand for renal replacement therapy.

A transplant from a live donor is generally considered to be the preferred form of RRT due to a combination of factors. Firstly, the shortage of deceased organ donors in all countries, including New Zealand, means that, for most people, there is little chance of ever receiving a deceased donor kidney transplant. The level of demand for kidney transplants combined with a shortage of potential deceased donors (arising in part from factors such as improved road safety) mean that, even if all potential deceased donors could be utilised, it is unlikely this would be sufficient to meet demand for kidneys (see for example R Coppen, Friele, Gevers, Blok, \& Van Der Zee, 20o8; Sheehy, Conrad, Brigham, \& Luskin, 2003).

Furthermore, a live transplant is more effective than dialysis in terms of both life expectancy and quality of life, and also offers increased life expectancy compared to a transplant from a deceased donor (Abecassis, et al., 2008; Ko \& Cosimi, 2001). Transplantation is considerably more cost effective than dialysis. Live transplantation provides better outcomes than deceased transplantation and, therefore, is even more cost effective. With respect to live transplantation, commentators note that it is rare in health policy to come across an intervention that is so unequivocally more effective and more cost effective than the alternative (Huang, et al., 2008).

Accurate cost data is not currently available in New Zealand. Based on 2003-04 estimates (cited in Central Region's Technical Advisory Services (TAS), 2007), it is estimated to cost up to $\$ 63,000$ per annum to treat someone on dialysis (varying depending on type of dialysis and delivery modality) compared to around $\$ 10,000$ per annum for someone with a functioning transplant. Tak- 
ing into account the upfront cost of the transplant itself (estimated at around $\$ 85,000$ ), live transplants can pay for themselves in around 18 months to two years and on-going costs are significantly less than for dialysis allowing for bankable savings of up to $\$ 53,000$ per year per patient.

There are risks involved in any major surgery and the wellbeing of donors has been of major concern since the days of the first live kidney transplant (Murray, 1992). Peri-operative mortality of live kidney donors (death within 90 days after the surgery) is commonly estimated to be around two to three per 10,000 (F. Delmonico, 2005; Jakobsen, 1997; Matas, 2008). There are relatively few large scale studies on long-term donor outcomes. Those that exist, however, conclude that there is no evidence of long-term complications (such as increased risk of renal failure) or impacts on long-term survival rates for live kidney donors (Ko \& Cosimi, 2001; Matas, 2008; Segev, et al., 2010). International guidelines for the selection and care of donors (e.g. such as those developed at the Amsterdam Forum (F. Delmonico, 2005)) stress that donor safety is paramount. Even though the benefits to recipients are significant, it is the relatively low risks to donors that makes live renal transplantation justifiable (Ko \& Cosimi, 2001; Sanner, et al., 2011) and means it is considered ethically acceptable in the right circumstances. For example, the World Health Organisation's guiding principles on organ donation state that 'live donations are acceptable...when professional care of donors is ensured and follow-up is well organised and when selection criteria for donors are scrupulously applied and monitored' (World Health Organisation, 2008, Guiding Principle 3). In terms of the psychosocial impacts on donors, some early studies of transplants in the United States highlighted the mix of feelings that live donors could experience, including being pressured into donation by family members (Fox \& Swazey, 1978, 1992). However, as Fellner and Marshall (1968:2705) noted, some 'donors reported that this had been a very meaningful experience in their lives, of substantial impact on them, and that it had brought about changes in them which they felt were beneficial' using words like 'noble,' 'bigger', and 'happier' to describe their feelings. More recent studies consistently show that the vast majority of donors report being happy with the decision to donate and experience increased self-esteem and well-being as a result. Negative feelings are often related to the failure of the transplant (Clemens, et al., 2006).

It is this combination of factors, therefore, that makes live renal transplantation the preferred treatment for many renal patients. 


\section{Gap between supply and demand}

As in other countries, there is a significant and growing gap between the number of people who might benefit from a transplant and those who receive one. Figure 1 shows that, in 2009, the official waiting list $^{1}$ for a kidney transplant was 617 , while 121 people received a transplant from either a deceased or live donor. However, the number of people on dialysis was far higher than the official waiting list, at 2,260, and is growing at a faster rate than both the waiting list and the number of transplants performed. While not everyone on dialysis would be suitable for a transplant, it is likely that many more people than those on the official waiting list would benefit from one. Waiting lists typically do not reflect the true level of demand for transplants often being restricted, due to the shortage of deceased donor organs, to those people who would benefit most from a transplant. Some studies estimate that only 20 per cent of dialysis patients are on transplant waiting lists despite estimates that up to half would live longer with a transplant than on dialysis (Gaston, 2009).

As shown in Figure 2, the number of live transplants in New Zealand has increased from 46 per annum in 2005 to 60 in 2010 , although there were fewer live transplants in 2010 than in the previous two years. In addition, the proportion of live donations to deceased has gradually increased over the years. In

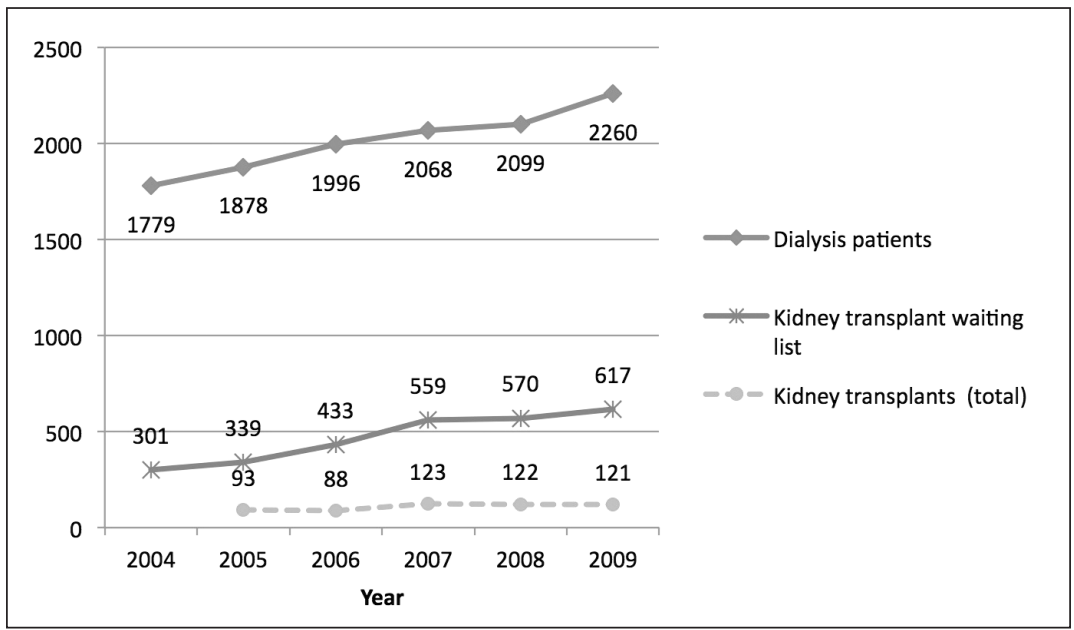

Figure 1. Number of dialysis patients, people on kidney transplant waiting list and transplants, 2004-2009. Sources: Dialysis and waiting list numbers from ANZDATA $(2009)^{2}$; transplant numbers from Organ Donation New Zealand (2009) 


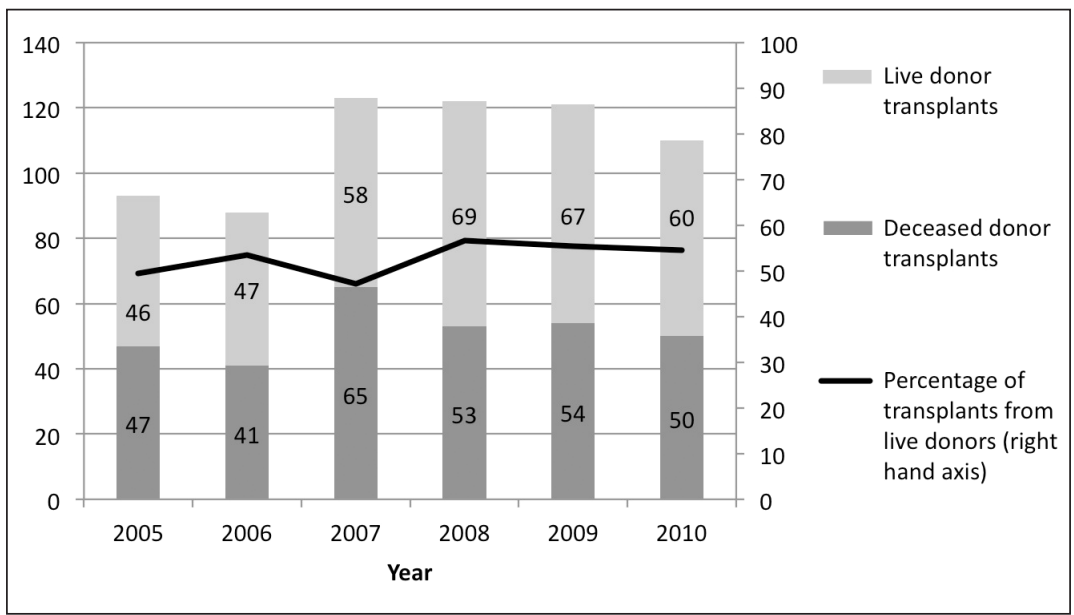

Figure 2. Numbers of deceased and live kidney transplants in New Zealand, 2005-2010. Based on data from Organ Donation New Zealand Annual Reports 2009, 2010 (Organ Donation New Zealand, 2009 and 2010).

2010, there were 110 kidney transplants, with 55 per cent being from live donors, compared to 49 per cent of transplants in 2005 being from live donors.

Maori and Pacific peoples are more likely to have end stage renal failure than other groups (Best Practice, 2009). Of the 492 new ESRF patients in 2008, 151 (30 per cent) were Maori and 84 (17 per cent) were Pacific (ANZDATA, 2009). A consistent finding internationally is the lower levels of transplantation for many indigenous and ethnic minority groups (see for example Cass, et al., 2004; Prasad, 2007; Yeates, et al., 2009). In Canada, New Zealand, Australia and the United States, transplant rates (both live and deceased) for indigenous populations are approximately one-third to one-half those of non-indigenous populations (Cass, et al., 2004). In New Zealand in 2008, 10\% of transplant recipients were Maori and 8 per cent were Pacific, compared to the 76 per cent for Pakeha (ANZDATA, 2009).

Higher rates of end-stage renal failure and lower transplantation rates account for higher rates of dialysis treatment among these groups (ANZDATA, 2009). Differential access to transplantation for Maori and Pacific peoples is a particular concern given it is the preferred treatment for kidney failure. Possible reasons for this gap may include patient preferences, health practitioners' attitudes, lack of culturally-appropriate education programs (for patients and 
potential donors), delayed referral for transplant evaluation, and delays from initial referral to wait-listing (Yeates, et al., 2009). Geographical factors (especially for remote communities), difficulty explaining treatment options (due to cross-cultural communication issues), how clinicians relate to patients, organ allocation algorithms that may impede access for some groups and community attitudes to transplantation may also have an impact (Cass, et al., 2004). Late referral has been shown to be associated with being less likely to receive a transplant and Ashton and Marshall note that differences in access rates to primary care services for Maori and Pacific peoples may influence how quickly those with renal disease are referred for specialist treatment (Ashton \& Marshall, 2007).

THE ISSUE

Consequences of not increasing New Zealand's rates of LRT

Maximising health outcomes within available funding (i.e. maximising value for money) is a key objective of the New Zealand public health system according to the New Zealand Public Health and Disability Act (2000) (Section 3). The growing rates of end-stage renal failure, with consequent burgeoning dialysis costs, might suggest that health care policy makers and health professionals would have good reasons to maximise the use of live kidney transplantation (Hilhorst, Kranenburg, \& Busschbach, 2007). In a system that is charged with providing the best possible health outcomes in the most cost-effective way, it is perhaps surprising that improving rates of live kidney transplantation is not more of a priority on the policy agenda.

Increasing New Zealand's live renal transplant rate would improve health outcomes for patients and reduce fiscal pressure on the health system. Maori and Pacific peoples in particular are likely to benefit from an increase in live transplant rates given their disproportionate dependence on dialysis. It would also contribute to addressing the growing problem of illegal and dangerous international organ trafficking (see for example Hippen, Ross, \& Sade, 2009; Omar, Tufveson, \& Welin, 2010) to which some New Zealanders needing transplants are reportedly turning in desperation (Hunt, 2010).

\section{There are no easy answers}

Responses to the problem of whether and how to increase rates of live renal transplantation are not straightforward, however. Live transplantation may be what is known as a 'wicked policy problem', defined as 'the deeply intractable 
issues which are imperfectly understood and to which solutions are not clear' (Stewart, 1998 as cited in Hunter, 2003:17). The Australian Public Service Commission defines 'wicked' not as 'evil' but rather as 'highly resistant to resolution' (Australian Public Service Commission, 2007:3). 'Wicked' problems: are hard to define, are socially and morally complex, involve many stakeholders with different ideas about the cause of the problem and what to do about it, have unique characteristics that make it difficult to draw lessons from other similar problems, and require multi-faceted responses with a whole-system perspective (Australian Public Service Commission, 2007).

The inherent complexity of the LRT problem arises primarily from the fact that live transplantation is dependent on the supply of organs from third parties who must undergo unnecessary surgery but do not stand to benefit medically from the procedure themselves. This makes it different from many other health policy problems where the solution can often be found by deciding to spend more money. Festle, for example, refers to 'the "special nature of organ transplantation". Transplantation [is] unlike most medical procedures because it relie[s] on a very scarce resource: an organ voluntarily donated by another human being' (2010:63). The ethical issues underpinning live kidney transplantation relating to the safety of donors, and concerns about altruism and coercion, are what make this such a unique and complex problem (Price, 2000).

\section{Debate is dominated by the issue of financial incentives for live donors}

Internationally, the debate about how to increase rates of live transplantation is dominated (to the point of 'saturation' according to Scheper Hughes [2007]) by the controversial question of whether financial incentives for live donors should be introduced. Those such as Satel (2008) argue that relying on altruism alone to ensure a sufficient supply of donors has failed as a strategy, while others such as Davis (2011) believe that there are a range of other options that can, and should be tried, before turning to financial incentives.

As Mendoza has noted, however, the significant ethical and moral challenges inherent in such proposals 'outweigh the benefits of a legalised kidney market from the standpoint of most governments' (2010:264). In the meantime, patients continue waiting for a deceased donor with a reducing chance of success.

In New Zealand, there has been very little public debate about whether or how to increase rates of live kidney transplantation, with most focus on organ donation being on deceased donors. Changes to the Human Tissue Act, debate about Jackie Blue's Human Tissue (Organ Donation) Amendment Bill, 
and the Ministry of Health's review of the regulation of human tissue, for example, were all primarily about deceased organ donation (see for example Hansard 2006a, Hansard 2006b, Ministry of Health 2004). Occasionally, live kidney transplantation appears in the media under headlines such as 'Calls to pay donors for their organs' (Hunt, 2010), a suggestion that was immediately dismissed by the Minister of Health who said, 'We are not going to create a market for human organs by paying people to donate. To do so would create significant ethical issues' (as cited in Hunt, 2010). Consultation for the review of regulation of human tissue also found virtually no support for financial incentives for live donors (Ministry of Health, 2004).

Ethical concerns about coercion, exploitation of donors and commodification of bodies underpin debates about financial incentives (see for example Friedman \& Friedman, 2006; Hippen, et al., 2009; Price, 2000; Roth, 2007; Rothman, 2003). From a practical point of view, a narrow focus on financial incentives may have the effect of distracting attention from other potential options that may be less ethically controversial and more feasible to introduce.

\section{The policy question}

In summary, live kidney transplants have now been performed for over 50 years internationally and are part of the standard set of services provided to renal patients in New Zealand. They are generally regarded as a legitimate, ethical, safe and cost effective treatment when carried out in the right circumstances (Omar, et al., 2010; World Health Organisation, 2008). However, the growing gap between supply and demand requires new strategies to address the shortage of transplants. The policy question, then, is not whether or not to do live transplants but whether, and how, to find new ways to meet the demand that is not only effective but socially and ethically acceptable.

THE EXISTING KNOWLEDGE BASE

\section{Current knowledge base}

Much of the existing New Zealand organ transplantation research focuses on deceased transplantation more than live (see for example Phoenix Research, 2007). Mauri Ora Associates has carried out research into the barriers to transplantation (both live and deceased) for Maori and Pacific peoples, but focusing only on the perspectives of health professionals (Mauri Ora Associates, 2009a, 2009b). Shaw's research offers wider perspectives about New Zealand attitudes to organ donation (Shaw, 2010a, 2010b) as does Webb and Shaw's article in this 
volume. There is little, if any, research specifically focused on the question of how rates of live renal transplantation might be increased and the range of options that could be considered.

My own experiences as a donor and speaking with a number of other donors, patients, and friends and family, prompted my initial thinking about the factors that might affect people's willingness to donate. For example, I have been struck a number of times by the lack of quite basic information about transplantation that even close friends and family of patients seem to have, such as the consequences of having only one kidney or the likelihood of being a match with someone you are not related to. Given this is the pool from which most live donors are drawn, this lack of information may act as a barrier to donation.

Internationally, a range of strategies has attempted to address the possible barriers to live kidney transplantation (Davis, 2011). No country has managed to eliminate the gap between supply and demand; but the variation in live transplant rates internationally may provide some insights into which strategies might be more or less effective (Horvat, et al., 2009). In this section, I give a brief, and by no means comprehensive, overview of some of the key issues in the international, and some local, literature including: donor recruitment, information and education; compensation for donors; kidney paired exchange schemes; the role of beliefs and attitudes; and the importance of institutional and organisational arrangements.

\section{Donor recruitment, information and education}

The role of information and education in decisions to donate or not has been the subject of several studies, including what potential donors know about live donation, their fears and preferences, but also the fears, preferences and knowledge of potential recipients. Boulware et al. (2002) found that factors influencing the hypothetical willingness to donate to a relative included the time required for recovery in hospital and the size and appearance of the surgical scar. Like Waterman et al. (2006), they found many potential donors were not aware that newer laparoscopic techniques have greatly reduced pain, recovery time and the resulting scar.

Potential donors may also overestimate the risk of short- and long-term complications of live donation. Concern about long-term consequences of having only one kidney is one of the most common worries among potential donors, their families, and patients. Kranenburg et al. (2007) found that the main reason for reluctance to donate is fear for one's health after donation, while Boul- 
ware et al. (2002) comment that unrealistic concerns may act as disincentives to live donation. Stothers et al. found statistically significant differences in the knowledge of donors and non-donors on basic questions such as 'a person cannot spare a kidney because they are vital organs required for a healthy life' and 'long-term health problems in live donors are very rare after kidney donation' (2005:1109).

Patients also typically overestimate the risks to donors and underestimate the positive feelings that donors typically have about donation which may impact on their willingness to ask a potential donor (Waterman, et al., 2006).

Alongside this, many people underestimate the seriousness of kidney disease and the benefits of a transplant to a kidney patient, not realising that it is a fatal disease and that dialysis is a far less effective treatment than transplants. Richards suggests that diseases such as cancer and AIDs 'carry an entirely different symbolic significance to kidney failure, although all are fatal if left untreated' (2008:1718). One Australian doctor commented on the reaction most people have to a diagnosis of cancer compared to renal failure saying, 'People react really well when I tell them they're going to have to go on dialysis even though the life expectancy is about three years. They react much worse when it's prostate cancer with an expectancy of closer to 10 years' (as reported in Hudson, 2008).

In the transplantation field itself, this has often been reinforced with heart, lung and liver transplants often being referred to as 'life saving' while kidney transplants are referred to as being about improving 'quality of life' (Sharp, 1995). Organ Donation New Zealand's website currently states that, 'people waiting for a heart, lungs or liver will die without a successful transplant while those waiting for a kidney transplant lead lives restricted by long-term dialysis treatment' (Organ Donation New Zealand, 2008).

Potential donors may not even be aware that they could donate, with many people not knowing that, with advances in immunosuppressive medication, donors no longer have to be genetically related (see Delmonico \& Dew, 2007).

A significant issue is that patients themselves are usually responsible for finding their own donors as many health professionals feel that it is not their role to recruit donors. This has been the case since the early days of transplantation. Fox and Swazey, for example, found that physicians were concerned to ensure that they avoided any sense of pressure or coercion of potential donors who may already feel a sense of familial obligation to donate, noting that 'physicians 
have used the term 'moral blackmail' to conceptualise a subtle but very powerful form of organ extortion that can inadvertently result from their zealousness' (1978:7). Likewise, in recent NZ research:

Most members of the transplant teams were adamant that it was not their role to seek out donors, and many felt that any behaviour that might lead to the perception that they were 'chasing' a donor would be at best unprofessional and at worst unethical. This led to the widespread practice of leaving donor recruitment squarely in the hands of the patient and whanau many of whom... were uncertain or apprehensive about initiating such discussions (Mauri Ora Associates, 2009a:27).

For patients, asking someone to consider being a donor can be very difficult. Barnieh et al. (2011) found in a survey of people on the waiting list for a transplant, that 71 per cent of respondents identified not knowing how to ask someone for their kidney as the most significant barrier they faced. This difficulty can be based around concern for the donor's wellbeing, not wanting to pressure someone, embarrassment if they said no, not wanting to owe someone, guilt about the pain and costs involved for the donor, worry that the donor would later regret the decision, and concern about the impact on the relationship (Kranenburg, et al., 2007; Reese, et al., 2008; Rodrigue, Cornell, Lin, Kaplan, \& Howard, 2007; Waterman, et al., 2006).

Kranenburg et al. note that 'patients may feel that even sharing information or inviting their potential donors to an information meeting on live kidney donation, is a veiled way of asking for a kidney... The majority of patients on the waiting list are willing to accept a living kidney donor but are reluctant to discuss the issue of living donation with their potential donors' (2007: 970-971). Many people needing transplants consequently never ask anyone and instead wait for someone to volunteer (Kranenburg, et al., 2007; MacFarquhar, 2009; Waterman, et al., 2006). The importance of supporting patients to actively recruit donors is seen in studies showing that patients will interpret the absence of an unsolicited offer as lack of interest, whereas up to 30 per cent of potential donors who had not been asked indicated a willingness to consider live donation (Kranenburg, et al., 2007). Healy (2006) notes the importance in blood donation of 'the ask', citing surveys of non-blood donors who said the most common reason for not donating was that they had not been asked.

Internationally, suggestions relating to LRT for improving donor recruitment processes have included: better information and education for both recipients 
and potential donors (Barnieh, et al., 2011; Stothers, et al., 2005; Waterman, et al., 2006); training and support for patients in how to approach potential live donors (Reese, et al., 2008; Sanner, et al., 2011); and facilitated information sessions with family and friends of patients by social workers or trained educators (MacReady, 2009; Rodrigue, et al., 2007). Others have advocated a more active role for transplant clinic staff themselves in donor recruitment, similar to the approach taken in Norway where health professionals ask potential donors on behalf of a patient (Hilhorst, et al., 2007; Kranenburg, et al., 2007).

\section{Compensation for donors}

Other barriers may include the costs faced by donors, in particular loss of income while recovering from surgery, typically four to six weeks (Clarke, Klarenbach, Vlaicu, Yang, \& Garg, 2006). My experience has been that debates in New Zealand about compensation for lost income often suffer from confusion with debates about financial incentives, that international bodies regard as being quite clearly separate. The World Health Organisation's (2008) guiding principles on organ donation, for example, confirm that compensation, including for lost income, is acceptable while payment (or incentives) is not. The Ministry of Health has reported that compensation for donors was generally supported in consultation on the Human Tissue Bill, although a small minority thought that even compensation would represent commercialisation and lead to a market culture, rather than a gift culture (Ministry of Health, 2004). New Zealand currently only compensates donors for lost income to the level of the Sickness Benefit (Ministry of Social Development, 2011) which may act as a deterrent to some potential donors, or at least delay when a transplant can be carried out while donors provision for the time they have off work. This extra time on dialysis could well have a negative impact on the success of the transplant.

\section{Utilisation of donors - kidney paired exchange}

An area of focus internationally, and more recently in New Zealand, is how to utilise those people who do come forward as donors but who are not a suitable match for the person they are hoping to donate to. One estimate suggests that as many as 30 per cent of willing otherwise suitable donor/recipient pairs do not proceed to transplantation for this reason (Ferrari \& De Klerk, 2009). In order to overcome this problem, several countries have introduced paired exchange schemes in which two pairs of incompatible donor/recipients exchange donors. The transplants are performed simultaneously to avoid the risk of one donor pulling out once their person has received a kidney from the other 
donor. Ferrari and de Klerk (2009) suggest that routine two-way or three-way paired exchange and altruistic donor chains could increase rates of kidney transplants by between seven per cent and ten per cent. Legislative, ethical, logistical and financial barriers have all had to be addressed in establishing successful schemes internationally (see for example Remco Coppen, Friele, van der Zee, \& Gevers, 2010; De Klerk, et al., 2005; Ferrari \& De Klerk, 2009; Gentry, Montgomery, \& Segev, 2011).

\section{Beliefs and attitudes}

It is difficult to know what impact beliefs and attitudes of individuals or groups can have on decisions to donate or accept a transplant. It should be noted that there is often a conflation in the literature between deceased and live organ donation although, as Sharp notes, there are some important differences, not least because of the 'shadow of death' that pervades deceased but not live donation (Sharp, 2006:6) and subsequent beliefs and attitudes. It can be difficult to know whether views about deceased donation, which are more commonly researched, spill over or influence views about live donation.

International research often shows that stated attitudes about organ donation do not correspond with behaviour, especially for deceased donation where opinion polls often show very high levels of public support for deceased organ donation but with very low rates of actual donation or registration as a potential donor (Harrison, Morgan, \& Chewning, 2008; Moloney \& Walker, 2002). Others have argued that so-called 'fundamental beliefs' are often not fixed but open to change (Hilhorst, et al., 2007), while others have found that views about the desirability, or not, of transplantation are highly contextual and can depend on individual circumstances (Moloney \& Walker, 2002), for example, when someone finds they or a loved one needs a transplant.

In the New Zealand context, the question about the role of attitudes and beliefs is particularly pertinent to whether Maori and Pacific cultural beliefs about, for example, the body, death and dying can help explain differences in transplant rates between ethnic groups. Lewis and Pickering suggest this may be a possible factor although, note that these beliefs are not homogeneous within groups (Lewis and Pickering, 2003). Mauri Ora Associates also note that there is an 'enormous range of views and attitudes about transplantation and donation within the Maori and Pacific communities' (2009a:4). The Ministry of Health, in its consultation on the review of the regulation of human tissue, found that there were some Maori who expressed views about the body and organ transplantation such as 'whakapapa is affected and the body can never be separated 
from the spiritual in a Maori sense' (Ministry of Health, 2004:16), while others did not. Attitudes about organ transplantation within Pacific groups were also found to be different between younger and older people. Mauri Ora Associates found that clinicians felt that Maori and Pacific were willing to accept transplants, noting that, there were no clinicians who agreed with the statement 'Maori and Pacific people are generally uninterested in transplants', with many saying 'they are just as keen' and 'they are all interested' (2009a: 12). Mauri Ora Associates concluded that ' $(\mathrm{t})$ here is no single Maori or Pacific view that is universally accepted and/or enforced' (2009a:9).

As well as acknowledging the variety of views within groups, it is important to distinguish between how beliefs might impact differently on deceased and live organ donation. Traditional Maori beliefs, for example, may be particularly relevant to deceased organ donation but, as Lewis and Pickering (2003) point out, may be less relevant to live donation which may be considered more acceptable, especially within whanau. The challenge for policy and practice is how to effectively accommodate this variety of views, and not to exacerbate the lower rates of Maori and Pacific transplantation for example, by denying options to members of these groups to either donate or receive organs.

\section{The importance of systems, institutions and organisations}

While much of the literature focuses on the motivations and willingness of individuals to donate, a system-level approach, with a focus on the institutions and organisational context within which live transplantation occurs, may also be important. Healy's research into deceased donor organ and blood donation systems highlighted the importance of institutional and organisational factors in affecting donation rates. He argues that altruism in these contexts often needs to be facilitated, for example, rather than assuming that people will come forward spontaneously, a direct request can often be important. He found that non-blood donors, for example, frequently cited 'not being asked' or 'lack of opportunity' as the reasons for not donating. As he says, 'without the logistical effort that makes it possible to donate, possessing the willingness to give would not have any practical consequences' (Healy, 2006: 69).

Other system level barriers may also exist, such as the capacity of transplant programs to evaluate potential donors within a reasonable timeframe and to actually carry out transplant surgery, for example, the number of theatre slots available each month for transplants. It has also been suggested that the pricing model in the New Zealand health system (where DHB s pay each other for services provided) may act as a disincentive to carrying out more transplants 
because the price paid for transplants by non-transplanting DHBs does not reflect the true cost to the transplanting DHBs. This means they are subsidising those DHBs that send their patients to other DHBs for transplants (Ashton \& Marshall, 2007).

\section{CONCLUSIONS}

In conclusion, the gap between supply and demand for renal transplants is a significant and growing problem for both patients and government. The shortage of deceased donors makes LRT an important option for policy makers and health managers to consider, both in order to improve outcomes for renal patients and to reduce fiscal pressure on the health system. The difficulty of finding effective and acceptable solutions should not be underestimated, however, with the need to balance the desire to provide an effective treatment for patients with the need to minimise risks to donors, including avoiding undue pressure or coercion of potential donors. The brief review of the literature above gives some idea of the range of factors that may influence rates of LRT and provides a starting point for considering strategies for increasing current rates. Many of the specific initiatives mentioned in the international literature already exist to a greater or lesser extent in New Zealand transplant services. There is, however, little New Zealand-based research about the barriers to LRT, ways to enhance our existing policy and practice, or what new strategies may be effective for reducing the growing gap between supply and demand.

I suggest there is a need for research in New Zealand that focuses specifically on these issues and am currently undertaking research as part of my $\mathrm{PhD}$ in Public Policy at Victoria University of Wellington with the aim of informing policy and practice relating to LRT in New Zealand. I also suggest that as a 'wicked' policy problem, it is important to consider a range of options and understand the issue from many different perspectives, including those of people with end-stage renal failure, recipients of live transplants, live donors, health professionals, and others. Systemic and institutional factors, as well as factors at the individual or family level, also need to be considered in addressing this complex problem.

\section{NOTES}

1 Waiting list numbers fluctuate during the year as individuals come on to the list, leave it (due to death or receiving a transplant) or are temporarily suspended due to ill health. The official numbers for each year are calculated as at 1 January 
of the following year and include both active and suspended patients (personal communication, Organ Donation New Zealand, 4 February 2011).

22009 waiting list figure supplied by odnz (personal communication 4 February, 2011).

\section{REFERENCES}

Abecassis, M., Bartlett, S., Collins, A., Davis, C., Delmonico, F., Friedewald, J., et al. 2008 'Kidney transplantation as primary therapy for end-stage renal disease: a National Kidney Foundation/Kidney Disease Outcomes Quality Initiative (NKF/KDOQITM) conference, Clinical Journal of the American Society of Nephrology, 3(2): 471-48o.

AnZDATA. 2009 ANZDATA Registry Annual Report 2009 Available from http:// www.anzdata.org.au/v1/report_20o9.html

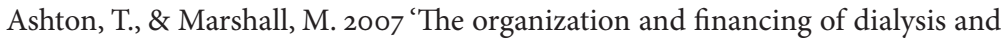
kidney transplantation services in New Zealand', International Journal of Health Care Finance and Economics, 7(4):233-252.

Australian Public Service Commission. 2007 Tackling Wicked Policy Pproblems: A Public Policy perspective, Canberra: Australian Public Service Commission.

Barnieh, L., McLaughlin, K., Manns, B., Klarenbach, S., Yilmaz, S., \& Hemmelgarn, B. 2011 'Barriers to living kidney donation identified by eligible candidates with end-stage renal disease', Nephrology Dialysis Transplantation, 26: $732-738$.

Best Practice. 2009 'Making a difference in chronic kidney disease: Part 1: catching renal impairment early', Best Practice Journal, 22:24-29.

Boulware, L., Ratner, L., Sosa, J., Tu, A., Nagula, S., Simpkins, C., et al. 2002 'The general public's concerns about clinical risk in live kidney donation', American Journal of Transplantation, 2(2):186-193.

Cass, A., Devitt, J., Preece, C., Cunningham, J., Anderson, K., Snelling, P., et al. 2004 'Barriers to access by indigenous Australians to kidney transplantation: The IMPA KT study', Nephrology, 9:144-146. 
Central Region's Technical Advisory Services (TAS). 2007 Renal Services in the Central Region: Strategic Direction and Opportunities for Regional Action. Wellington: TAS.

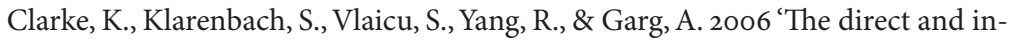
direct economic costs incurred by living kidney donors-a systematic review', Nephrology Dialysis Transplantation, 21(7):1952-1960.

Clemens, K., Thiessen Philbrook, H., Parikh, C., Yang, R., Karley, M., Boudville, N., et al. 2006 'Psychosocial health of living kidney donors: a systematic review', American Journal of Transplantation, 6(12):2965-2977.

Coppen, R., Friele, R., Gevers, S., Blok, G., \& Van Der Zee, J. 2008 'The impact of donor policies in Europe: a steady increase, but not everywhere', BMC Health Services Research, 8. Retrieved from http://www.biomedcentral.com/ content/pdf/1472-6963-8-235.pdf

Coppen, R., Friele, R., van der Zee, J., \& Gevers, S. 2010 'The potential of legislation on organ donation to increase the supply of donor organs', Health Policy, 98:164-170.

Davis, C. 2011 'How to increase living donation - global strategies to meet the organ need', Transplant International, 24 (4):344-349.

Davis, C., \& Delmonico, F. 2005 'Living-donor kidney transplantation: a review of the current practices for the live donor', Journal of the American Society of Nephrology, 16(7): 2098-2110.

De Klerk, M., Keizer, K., Claas, F., Witvliet, M., Haase Kromwijk, B., \& Weimar, W.

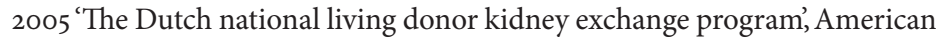
Journal of Transplantation, 5(9):2302-2305.

Delmonico, F. 2005 'A report of the Amsterdam Forum on the care of the live kidney donor: data and medical guidelines', Transplantation, 79(25):553-566.

Delmonico, F., \& Dew, M. 2007 'Living donor transplantation in a global environment', Kidney International, 71: 608-614.

Fellner, C., \& Marshall, J. 1968 ‘Twelve kidney donors', JAMA, 206(12):2703-2707. 
Ferrari, P., \& De Klerk, M. 2009 'Paired kidney donations to expand the living donor pool', Journal of Nephrology, 22(6): 699-707.

Festle, M. 2010 'Enemies or allies? The organ transplant medical community, the federal government, and the public in the United States, 1967-2000', Journal of the History of Medicine and Allied Sciences, 65(1):48-60.

Fox, R., \& Swazey, J. 1978 The Courage to Fail. Chicago: The University of Chicago Press.

Fox, R., \& Swazey, J. 1992 Spare Parts. New York: Oxford University Press.

Friedman, E. A., \& Friedman, A. L. 2006 'Payment for kidney donors: pros and cons', Kidney International, 69:960-962.

Gaston, R. 2009 'Must health literacy be a prerequisite for kidney transplantation?', Clinical Journal of the American Society of Nephrology, 4(1):16-17.

Gentry, S., Montgomery, R., \& Segev, D. 2011 'Kidney paired donation: fundamentals, limitations, and expansions', American Journal of Kidney Disease, 57(1):144-151.

Hansard 2006a Parliamentary Debates for Tuesday 14 November 2006: Human Tissue Bill-First Reading. Retrieved 31 May 2011, from http://www.parliament.nz/en-NZ/PB/Debates/Debates/4/c/7/48HansD_20o61114_oooo1281Human-Tissue-Bill-First-Reading.htm

Hansard 2006b Parliamentary Debates for Wednesday 3 May 2006: Human Tissue (Organ Donation) Amendment Bill-First Reading. Retrieved 31 May 2011, from http://www.parliament.nz/en-NZ/PB/Debates/Debates/ f/6/a/48HansD_20060503_oooo126o-Human-Tissue-Organ-DonationAmendment-Bill.htm

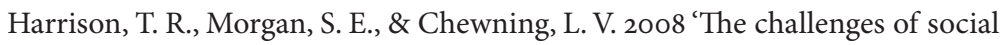
marketing of organ donation: news and entertainment coverage of donation and transplantation', Health Marketing Quarterly, 25(1):33-65.

Healy, K. 2006 Last Best Gifts: Altruism and the Market for Blood and Organs. Chicago: University of Chicago Press. 
Hilhorst, M., Kranenburg, L., \& Busschbach, J. 2007 'Should health care professionals encourage living kidney donation?', Medicine, Health Care and Philosophy, 10(1): 81-9o.

Hippen, B., Ross, L., \& Sade, R. 2009 'Saving lives is more important than abstract moral concerns: financial incentives should be used to increase organ donation', The Annals of Thoracic Surgery, 88(4):1053-1061.

Horvat, L., Shariff, S., \& Garg, A. 2009 'Global trends in the rates of living kidney donation', Kidney International, 75(10):1088-1098.

Huang, E., Thakur, N., \& Meltzer, D. 2008 'The cost-effectiveness of renal transplantation', In S. Satel (ed.) When Altruism Isn't Enough: The Case for Compensating Kidney Donors. Washington DC: AEI Press.

Hudson, R. 2008 'Scare tactics', Sunday Star Times, May 18 2008: C4.

Hunt, T. 2010 'Call to pay donors for their organs', The Dominion Post, April 8 2010.

Hunter, D. 2003 Public Health Policy. Cambridge: Polity Press.

Jakobsen, A. 1997 'Living renal transplantation-the Oslo experience', Nephrology Dialysis Transplantation, 12(9), 1825-1827.

Ko, D., \& Cosimi, A. 2001 'The donor and donor nephrectomy', In P. Morris (ed.) Kidney Transplantation: Principles and Practice ( 5 ed.). United States: W.B. Saunders.

Kranenburg, L., Zuidema, W., Weimar, W., Hilhorst, M., IJzermans, J., Passchier, J., et al. 2007 'Psychological barriers for living kidney donation: how to inform the potential donors?', Transplantation, 84(8): 965-971.

Lewis, G. and Pickering, N. 2003 'Maori spiritual beliefs and attitudes towards organ donation', New Zealand Bioethics Journal, 4:31-35

MacFarquhar, L. 2009 'The kindest cut', The New Yorker, 27 July 2009:38-51.

MacReady, N. 2009 'Educating CKD patient's family encourages kidney donation', Medscape Medical News. Retrieved from http://www.medscape.com/ viewarticle/711811 
Matas, A. 2008 'Risks of kidney transplantation to a living donor', In S. Satel (ed.) When Altruism Isn't Enough: The Case for Compensating Kidney Donors. Washington DC: AEI Press.

Mauri Ora Associates. 2009a Maori and Pacific Attitudes Towards Transplantation: Professional Perspectives. Wellington: Ministry of Health.

Mauri Ora Associates. 2009b Maori and Pacific People's Attitudes towards Transplantation: A Literature Review by Mauri Ora Associates. Wellington: Ministry of Health.

Mendoza, R. L. 2010 'Kidney black markets and legal transplants: Are they opposite sides of the same coin?', Health Policy, 94:255-265.

Ministry of Health. 2004 Review of the Regulation of Human Tissue and Tissuebased Therapies: Submissions Summary. Wellington: Ministry of Health. Retrieved 10 February 2011, from http://www.moh.govt.nz/moh.nsf/o/Bo 48B13B83ADD631CC256F1DoooAA1DE/\$File/submissionssummary.pdf

Ministry of Health. 2006 The Demand for Renal Replacement Therapy: Projections for 2005-2019. Retrieved 12 April 2011, from http://www.maorihealth. govt.nz/moh.nsf/Files/nrab/\$file/renal-replacement-therapy-projections-20052019.pdf

Ministry of Social Development. 2011 Live Organ Donor Assistance. Retrieved 28 February 2011, from http://www.workandincome.govt.nz/individuals/ a-z-benefits/live-organ-donor-assistance.html

Moloney, G., \& Walker, I. 2002 'Talking about transplants: social representations and the dialectical, dilemmatic nature of organ donation and transplantation', The British Journal of Social Psychology, 41:299.

Murray, J. 1992 'Human organ transplantation: Background and consequences', Science, 256(5062):1411-1146.

New Zealand Government. 2000 New Zealand Public Health and Disability Act. Retrieved from http://www.legislation.govt.nz/act/public/200o/oo91/latest/ DLM8oo51.html?search=ts_act_public+health+and+disability_resel\&p=1

Omar, F., Tufveson, G., \& Welin, S. 2010 'Compensated living kidney donation: a plea for pragmatism', Health Care Analysis, 18(1):85-101. 
Organ Donation New Zealand. 2008 Waiting list times. Retrieved 29 November 2010, from http://www.donor.co.nz/donor/transplants/waiting_lists.php

Organ Donation New Zealand. 2009 Annual Report 2009. Retrieved from http:// www.donor.co.nz/donor/images/odnz_2009_annual_report.pdf

Organ Donation New Zealand. 2010 Annual Report 2010. Retrieved from http:// www.donor.co.nz/donor/images/odnz_2010_annual_report.pdf

Phoenix Research. 2007 Research to Support Initiatives to Maximise Organ and Tissue Donation: Research Report for the Ministry of Health. Wellington: Ministry of Health.

Prasad, G. 2007 'Renal transplantation for ethnic minorities in Canada: inequity in access and outcomes?', Kidney International, 72(4):390-392.

Price, D. 2000 Legal and Ethical Aspects of Organ Transplantation. Cambridge: Cambridge University Press.

Reese, P., Shea, J., Berns, J., Simon, M., Joffe, M., Bloom, R., et al. 2008 'Recruitment of live donors by candidates for kidney transplantation', Clinical Journal of the American Society of Nephrology, 3(4):1152-1159.

Richards, R. 2008 'Writing the othered self: Autoethnography and the problem of objectification in writing about illness and disability', Qualitative Health Research, 18(12):1717-1728.

Rodrigue, J., Cornell, D., Lin, J., Kaplan, B., \& Howard, R. 2007 'Increasing live donor kidney transplantation: a randomized controlled trial of a home-based educational intervention' American Journal of Transplantation, 7(2):394401.

Roth, A. 2007 'Repugnance as a constraint on markets', The Journal of Economic Perspectives, 21(3):37-58.

Rothman, D. 2003 Strangers at the Bedside: A History of How Law and Bioethics Transformed Medical Decision-Making. New York: Walter de Gruyter, Inc.

Sanner, M., Lagging, E., \& Tibell, A. 2011 'The kidney recipient's path to transplantation: a comparison between living and deceased kidney donor recipients in Stockholm, Sweden', Nephrology Dialysis Transplantation, 26:1053-1057. 
Satel, S. (ed.) 2008 When Altruism Isn't Enough: The Case for Compensating Kidney Donors. Washington DC: AEI Press.

Scheper Hughes, N. 2007 'The tyranny of the gift: sacrificial violence in living donor transplants', American Journal of Transplantation, 7(3):507-511.

Segev, D., Muzaale, A., Caffo, B., Mehta, S., Singer, A., Taranto, S., et al. 2010 'Perioperative mortality and long-term survival following live kidney donation', JAMA, 303(10): 959-966.

Sharp, L. 1995 'Organ transplantation as a transformative experience: anthropological insights into the restructuring of the self', Medical Anthropology Quarterly, 9(3):357-389.

Sharp, L. 2006 Strange Harvest: Organ Transplants, Denatured Bodies and the Transformed Self. Berkley: University of California Press.

Shaw, R. 2010a 'Organ donation in Aotearoa/New Zealand: cultural phenomenology and moral humility', Body \& Society, 16(3):127-147.

Shaw, R. 2010b 'Perceptions of the gift relationship in organ and tissue donation: views of intensivists and donor and recipient coordinators', Social Science \& Medicine, $70(4): 609-615$.

Sheehy, E., Conrad, S., Brigham, L., \& Luskin, R. 2003 'Estimating the number of potential organ donors in the United States', The New England Journal of Medicine, (August 14). Retrieved from http://search.proquest.com/docprin tview/223928339? accountid $=14782$

Stein, A., \& Wild, J. 2002 Kidney Failure Explained. London: Class Publishing.

Stothers, L., Gourlay, W. A., \& Liu, L. 2005 'Attitudes and predictive factors for live kidney donation: a comparison of live kidney donors versus nondonors', Kidney International, 67:1105-1111.

Waterman, A., Stanley, S., Covelli, T., Hazel, E., Hong, B., \& Brennan, D. 2006 'Living donation decision making: recipients' concerns and educational needs', Progress in Transplantation 16(1):17-23.

World Health Organisation. 2008 w Ho Guiding Principles on Human Cell, Tissue and Organ Transplantation. Retrieved 17 November 2010, from http://www. 
Article $\cdot$ Martin

who.int/transplantation/TxGPo8-en.pdf

Yeates, K., Cass, A., Sequist, T., McDonald, S., Jardine, M., Trpeski, L., et al. 2009 'Indigenous people in Australia, Canada, New Zealand and the United States are less likely to receive renal transplantation', Kidney International, 76(6): 659-664. 